\title{
Efektifitas Permainan Sirkuit Dalam Menstimulus Kemampuan Motorik Halus Anak Usia Dini
}

\author{
Made Vina Arie Paramita1, Vivi Supiati ${ }^{2}$ \\ Universitas Pendidikan Ganesha \\ $\underline{\text { Email.vina.arie@undiksha.ac.id'; vivisupiati@gmail.com² }}$
}

\begin{abstract}
Abstrak
Penelitian ini bertujuan untuk mengetahui keefektifan penerapan permainan sirkuit dalam menstimulus kemampuan motorik halus anak usia dini. Penelitian ini merupakan penelitian kuantitatif dengan metode kuasi eksperimen. Teknik dan instrument pengumpulan data dengan menggunakan wawancara, lembar observasi dan lembar validasi atau angket. Teknik analisis data uji efektivitas yang digunakan adalah dengan analisis statistik nonparametrik Uji Wilcoxon atau uji tanda. Jumlah sampel yang digunakan dalam penelitian ini berjumlah 14 anak. Adapun hasil dari analisis data menunjukkan $\mathrm{J}$ - adalah 2 dan nilai $\mathrm{J}$ tabel untuk $\mathrm{N}=13$ adalah 17 , sehingga dapat dilihat bahwa $\mathrm{J}$ - $<$ dari $\mathrm{J}$ tabel $(2<17)$, sehingga dapat disimpulkan bahwa permainan sirkuit efektif dalam menstimulus kemampuan motorik halus anak usia dini.

Kata Kunci: Model Pembelajaran; Permainan Sirkuit;, Permainan Sirkuit, Motorik Halus,

This study aims to determine the effectiveness of the application of circuit games in stimulating fine motor skills in early childhood. This research is a quantitative study with a quasiexperimental method. Data collection techniques and instruments using interviews, observation sheets and validation sheets or questionnaires. The data analysis technique for the effectiveness test used is the nonparametric statistical analysis Wilcoxon test or sign test. The number of samples used in this study amounted to 14 children. The results of the data analysis show that $J$ - is 2 and the value of $J$ table for $N=13$ is 17 , so it can be seen that J- <from $J$ table $(2<17)$, so it can be concluded that circuit play is effective in stimulating children's fine motor skills. early age.
\end{abstract}

Keyword: Learning model; Circuit Games; Circuit Games, Fine Motorics, .

\section{PENDAHULUAN}

Anak merupakan generasi penerus bangsa yang memerlukan perhatian khusus dalam tumbuh kembang. Setiap anak memiliki pertumbuhan dan perkembangan yang berbeda-beda sesuai dengan kebutuhan, sehingga anak disebut pribadi yang unik. Piaget menyatakan anak lahir dengan segala keunikan potensi, yang antara satu dengan yang lainnya tidak sama, bahkan anak kembar sekali pun(Faris \& Lestari, 2016; Khaironi, 2018). Hal ini mengartikan bahwa setiap anak adalah unik karena memiliki watak, perawakan yang berbeda-beda.

Keunikan pada anak juga terlihat pada proses perkembangan. Anak usia dini merupakan kelompok anak yang berada dalam proses pertumbuhan dan perkembangan yang bersifat unik, artinya memiliki pola pertumbuhan dan perkembangan fisik (koordinasi motorik kasar dan motorik halus), kecerdasan (daya pikir dan daya cipta), sosio emosional, bahasa 
dan komunikasi. Seluruh aspek perkembangan baik fisik motorik, kognitif, bahasa, dan sosial emosional anak akan berkembang sesuai dengan tahapan perkembangan. Setiap aspek perkembangan anak tersebut secara umum memiliki pola atau tahapan perkembangan yang sama, namun pencapaian setiap anak terhadap masing-masing aspek perkembangan yang berbeda. Perbedaan ini karena dipengaruhi dari kesiapan atau biasanya disebut masa peka(Britto et al., 2017; Yudiwinata \& Handoyo, 2014).

Masa peka merupakan kondisi kesiapan anak dalam menerima rangsangan atau stimulus. Artinya, pada masa ini mempermudah anak dalam mempelajari dan membangun pola pikir tentang segala sesuatu yang berada di sekitar tanpa merasa ada kesulitan. Montessori menjelaskan dalam tahun-tahun awal kehidupan, seorang anak mempunyai masa peka. Masa peka dapat digambarkan sebagai suatu situasi atau waktu siap berkembang pembawaan atau potensi yang dimiliki anak. Potensi ini akan lenyap dan tidak akan muncul lagi apabila anak tidak diberikan kesempatan untuk berkembang tepat pada waktunya. Oleh karena itu, masa peka merupakan masa yang sangat penting dalam perkembangan seorang anak. Saat anak berada pada masa peka, maka anak harus distimulasi dengan cara yang sesuai prinsip pembelajaran anak yakni bermain(adawiyah agustina et al., 2015; Chairilsyah, 2019; Paramita \& Sutapa, 2019)

Bermain merupakan kegiatan yang sangat penting bagi pertumbuhan dan perkembangan anak. Kata "bermain" tidak lepas dari anak usia dini. Seluruh kegiatan anak lakukan dengan bermain. Bermain dilakukan dengan rasa senang dan aktif, sehingga kegiatan bermain tersebut menghasilkan proses belajar pada anak. Suasana yang senang, aktif, nyaman dan santai membuat anak tidak merasa tertekan, sehingga anak dapat menikmati kegiatan bermain. Bermain dapat digunakan sebagai media untuk menguatkan ketrampilan dan kemampuan tertentu pada anak. Kegiatan bermain merupakan cara terbaik menstimulasi anak untuk belajar mengekspresikan perasaan, pikiran dan pandangan terhadap seni(Elfiadi, 2016; Hasanah, 2016; Widyasari \& Sutapa, 2019). Banyak manfaat yang didapatkan oleh anak melalui bermain, seperti anak membangun pengetahuan, menjalin interaksi sosial dengan anak lain, melatih panca indra, melatih fisik-motorik, meningkatkan kemampuan bahasa yang dimiliki, melatih kesabaran, meningkatkan jiwa empati dan saling berbagi. Pada perkembangan aspek fisik, anak berkesempatan melakukan kegiatan yang melibatkan gerakan tubuh dan melatih otot-otot tubuh. Bermain membutuhkan gerakan dan koordinasi tubuh, sehingga dengan bermain anak dapat melepaskan ketegangan yang ada dalam dirinya. Anak akan menyalurkan perasaan dan dorongan-dorongan yang membuat anak merasa lebih lega dan relaks. Pada dasarnya, melalui bermain akan menstimulasi seluruh aspek perkembangan anak.

Aspek perkembangan anak saling berkaitan yang satu dengan yang lainnya. Seluruh aspek perkembangan harus distimulasi dengan berbagai kegiatan yang menyenangkan. Salah satu aspek perkembangan yang wajib distimulasi adalah perkembangan fisik-motorik. Perkembangan fisik menjadi dasar, artinya disini adalah pertama kali yang dapat anak lakukan dalam menanggapi respon melalui gerakan. Anak menggenggam, menoleh, menendangnendang, dan lain sebagainya merupakan bagian dari perkembangan fisik(Novitasari et al., 2019; Fitriani \& Adawiyah, 2018).

Perkembangan fisik ada dua aspek, yakni perkembangan motorik kasar dan perkembangan motorik halus. Istilah fisik motorik menggambarkan semua gerakan tubuh dan diklasifikasikan menjadi motor kasar dan perilaku motorik halus. Motorik halus digunakan dalam kegiatan pada kehidupan sehari-hari dan pada akademik. Kegiatan pada perkembangan motorik halus yang biasa dilakukan dalam kehidupan sehari-hari, contohnya menyikat gigi, memakai pakaian, menggunakan sendok dan garpu, mengikat tali sepatu, dan lain sebagainya. Pada kegiatan akademik yang biasa dilakukan anak seperti menulis, menggunting, mewarnai, 
melipat, menggambar dan menarik garis, dan lain sebagainya.(Effi Kumala Sari, 2014; Maghfuroh, 2018).

Kemampuan motorik halus adalah pola gerakan untuk memanipulasi objek dengan menggunakan otot kecil tangan dan jari. Fakhruddin menjelaskan motorik halus adalah meningkatkan pengoordinasikan gerak tubuh yang melibatkan kelompok otot dan saraf yang lebih kecil". Kelompok otot dan saraf inilah yang nantinya mampu mengembangkan gerak motorik halus, misal, merobek, menggambar dan menulis. Sejalan dengan pendapat tersebut, Keterampilan motorik halus adalah kemampuan manipulatif yang melibatkan gerakan dan otot-otot kecil pada bagian tubuh. Pengembangkan kemampuan motorik halus harus membutuhkan kesabaran dan latihan untuk berkembang(Effi Kumala Sari, 2014; Muarifah \& Nurkhasanah, 2019).

Pada dasarnya perkembangan ini berkembang sejalan dengan kematangan saraf dan otot anak. Sehingga, setiap gerakan sesederhana apapun, adalah merupakan hasil pola interaksi yang kompleks dari berbagai bagian dan sistem dalam tubuh yang dikontrol oleh otak. Perkembangan motorik sebagai perkembangan dari unsur kematangan dan pengendalian gerak tubuh. Fakta yang ada di lapangan, masih ada yang selalu mengedepankan akademik anak tanpa memperhatikan kesiapan anak. Contohnya, anak sudah diajarkan menulis tanpa melihat apakah anak sudah siap memegang pensil, apakah otot-otot anak sudah mampu. Anak lebih senang melakukan kegiatan di luar ruangan karena anak merasa lebih renggang dan bebas, namun sebagian besar kegiatan pembelajaran masih dilakukan di dalam ruangan kelas. Kegiatan yang dilakukan di dalam ruangan kelas dengan menggunakan lembar kerja anak (LKA). Kegiatan- kegiatan pembelajaran lebih sering bersifat individual dan masih bersifat monoton. Pembelajaran masih bersifat konvensional, guru masih menjadi pusat segalanya. Hal tersebut mengakibatkan anak merasa bosan dan kurang begitu tertarik dengan pembelajaran, sehingga membutuhkan inovasi model pembelajaran yang menarik perhatian anak.

Berdasarkan fakta tersebut ada 3 masalah yang muncul, yakni: (1) pembelajaran masih mengedepankan akademik seperti membaca, menulis dan berhitung, sehingga kurangnya perhatian untuk merangsang perkembangan motorik halus anak; (2) kegiatan pembelajaran sebagian besar masih dilakukan di dalam kelas, sehingga anak kurang memiliki variasi kegiatan di luar ruangan yang menyebabkan anak mudah bosan melakukan kegiatan di dalam kelas; (3) alternatif kegiatan pembelajaran dalam menstimulus motorik halus anak kurang bervariasi, sehingga anak cenderung tidak mau menyelesaikan pekerjaan.

\section{METODE PENELITIAN}

Penelitian ini merupakan penelitian kuantitatif dengan metode kuasi eksperimen.. Rancangan penelitian ini untuk melihat seberapa efektif yang diberikan oleh variabel bebas yaitu permainan sirkuit terhadap variabel terikat yaitu motorik halus, sebelum diberi perlakuan dan setelah diberi perlakuan. Rancangan penelitian menggunakan pretest dan posttest dalam satu kelompok dengan metode penelitian pre-experimental design bentuk one-group pretest-posttest design ((Sugiyono, 2016)).

\section{$\mathrm{O}_{1} \mathrm{X} \mathrm{O}_{2}$}

Pada penelitian ini subyek penelitian memfokuskan pada anak yang berusia 4-5 tahun. Subjek pada penelitian ini adalah Kelompok A di TK Negeri Pembina Umbulharjo sebanyak 
14 anak. Pengumpulan data digunakan sebagai alat untuk mengukur sebuah penelitian. Teknik pengumpulan data yang digunakan pada penelitian ini adalah teknik pengumpulan data dengan wawancara, angket validasi, dan observasi. Teknik analisis data dalam penelitian ini berbedabeda sesuai dengan proses penilaian yang dijalankan dan instrumen yang digunakan. Analisis data yang digunakan pada penelitian ini adalah metode analisis deskriptif kualitatif dan analisis deskriptif kuantitatif. Pada uji efektifitas dilakukan dengan uji nonparametrik dengan uji Wilcoxon atau uji peringkat bertanda. Syarat diterimanya Ho apabila J lebih kecil atau sama dengan nilai tabel untuk N pasang ((Syahrum \& Salim, 2012)

\section{HASIL DAN PEMBAHASAN}

Hasil

Hasil penelitian merupakan hasil deskripsi data atau gambaran yang diperoleh untuk mendukung hasil penelitian. Berdasakan hasil praktek di TK Negeri Pembina Umbulharjo, penerapan kegiatan motorik halus menggunakan permainan sirkuit. Berikut sajian data dari hasil pretest yang berhubungan kemampuan motorik halus anak sebelum diberikan perlakuan dengan permainan sirkuit.

Tabel 1. Deskripsi Data Hasil Penelitian

\begin{tabular}{|c|c|c|}
\hline & Pretest & Postest \\
\hline Jumlah Subjek & 14 & 14 \\
\hline Mean & 10,3 & 11,93 \\
\hline Median & 10,5 & 12 \\
\hline Modus & 11 & 12 \\
\hline Varians & 1,45 & 1,61 \\
\hline Standar Deviasi & 1,20 & 1,26 \\
\hline
\end{tabular}

Tabel 2. Hasil Uji Keefektifan dengan Uji Wilcoxon

\begin{tabular}{|l|c|c|c|c|c|c|c|c|c|c|c|c|c|c|}
\hline $\begin{array}{l}\text { Subjek } \\
\text { Penelitian }\end{array}$ & 001 & 002 & 003 & 004 & 005 & 006 & 007 & 008 & 009 & 010 & 011 & 012 & 013 & 014 \\
\hline Sebelum & 10 & 9 & 12 & 12 & 11 & 10 & 11 & 11 & 10 & 8 & 11 & 11 & 9 & 9 \\
\hline Sesudah & 12 & 11 & 14 & 12 & 10 & 11 & 13 & 14 & 12 & 10 & 12 & 13 & 12 & 11 \\
\hline Selisih & 2 & 2 & 2 & 0 & -1 & 1 & 2 & 3 & 2 & 2 & 1 & 2 & 3 & 2 \\
\hline Peringkat & 7,5 & 7,5 & 7,5 & $\mathrm{x}$ & 2 & 2 & 7,5 & 12,5 & 7,5 & 7,5 & 2 & 7,5 & 12,5 & 7,5 \\
\hline Positif & 7,5 & 7,5 & 7,5 & $\mathrm{x}$ & - & 2 & 7,5 & 12,5 & 7,5 & 7,5 & 2 & 7,5 & 12,5 & 7,5 \\
\hline J+ & 89 & & & $\mathrm{x}$ & & & & & & & & & & \\
\hline Negatif & - & - & - & $\mathrm{x}$ & 2 & - & - & - & - & - & - & - & - & - \\
\hline J- & 2 & & & $\mathrm{x}$ & & & & & & & & & & \\
\hline
\end{tabular}


Berdasarkan tabel 7 dan tabel 8 menunjukkan sehingga dapat dilihat bahwa J- lebih kecil dari J tabel, maka Ho ditolak. Dengan demikian dapat disimpulkan bahwa ada perubahan kemampuan motorik halus yang signifikan antara kemampuan anak sebelum dengan kemampuan anak sesudah perlakuan.

\section{Pembahasan}

Motorik halus digunakan dalam kegiatan pada kehidupan sehari-hari dan pada akademik. Sejalan dengan penelitian dari Spanaki menyatakan bahwa "the fine motor intervention program had a positive effect upon the graphomotor skills of kindergarten and early elementary school children". Pendapat tersebut menggambarkan jika program intervensi motorik halus memiliki dampak atau efek positif kepada keterampilan graphomotor TK dan anak SD awal. Pada usia 4-5 tahun perkembangan motorik halus anak belum seutuhnya sempurna, sehingga perlu mendapatkan stimulasi. Kegiatan diluar ruangan bisa menjadi pilihan terbaik karena dapat memberikan stimulasi perkembangan otot (baik kasar maupun halus). Peningkatan potensi psikomotorik anak akan lebih teroptimalkan jika lingkungan tumbuh kembang anak mendukung mereka untuk bergerak secara bebas (Chairilsyah, 2019; Muarifah \& Nurkhasanah, 2019; Paramita \& Sutapa, 2019).

Permainan sirkuit salah satu alternaif model pembelajaran yang dapat dilakukan diluar ruangan. Permainan sirkuit ini merupakan model pembelajaran yang berisikan pos-pos permainan yang bertujuan untuk menstimulasi aspek perkembangan anak khususnya motorik halus. Permainan sirkuit menekankan tentang bagaimana pengelolaan pembelajaran yang dilakukan melalui kegiatan anak yang memiliki alur dan aturan. Permainan sirkuit juga digunakan untuk menekankan tentang kegiatan pembelajaran yang bisa untuk menambah motivasi, minat, serta semangat anak dalam proses kegiatan pembelajaran. Adapun pos-pos kegiatan pada permainan sirkuit terdiri dari 4 pos kegiatan, yakni pos 1 adalah menuangkan air kedalam botol, pos 2 adalah mengancingkan benda, pos 3 adalah menjepit gambar dengan jepit jemuran, dan pos 4 adalah menggunting gambar.

Permainan sirkuit layak digunakan dalam proses pembelajaran untuk meningkatkan motorik halus anak. Hal ini dibuktikan dengan hasil tahap uji efektifitas yang dilaksanakan sebanyak 6 kali pertemuan (sudah termasuk pretest dan postest) dalam waktu satu bulan didapatkan hasil motorik halus anak meningkat. Peningkatan dilihat dari rata-rata yang meningkat sebesar 1,63 dari 10,3 menjadi 11,93. Pada penelitian ini Ho ditolak, hal ini ditunjukkan dari J- lebih kecil dari J tabel (2 lebih kecil dari 17). Dengan demikian dapat disimpulkan bahwa ada perubahan yang signifikan motorik halus antara kemampuan anak diawal dengan kemampuan anak diakhir perlakuan.

Pembelajaran yang baik adalah pembelajaran yang kegiatannya disenangi anak, sehingga anak menerima pembelajaran dengan perasaan tanpa beban. Bergen mengatakan "kunci dari bermain adalah menyenangkan. Jika suatu aktivitas tidak memberikan kesenangan, maka tidak bisa dikatakan bermain. (Madyawati, 2016) menyebutkan "dengan bermain sangat mendukung pertumbuhan dan perkembangan anak. Anak mulai untuk mengerti dunia, mampu mengembangkan pemikiran yang fleksibel dan berbeda serta memiliki kesempatan menemukan dan mengatasi permasalahan-permasalahan yang sebenarnya". Bermain merangsang pemikiran anak dalam memproses pemecahan masalah yang ditemuinya. Dengan demikian anak akan semakin mengerti solusi yang harus diberikan pada setiap masalah yang ditemui.

Permainan yang digunakan dalam mengembangkan kemampuan motorik halus anak berupa permainan sirkuit. Permainan Sirkuit merupakan modifikasi dari sirkuit training, 
pengertian dari permainan sirkuit tidak jauh beda dari latihan sirkuit yakni kegiatan yang terdiri dari serangkaian bentuk latihan yang dilakukan. menyebutkan sirkuit merupakan model latihan yang dilakukan secara berurutan dan terus menerus selama satu putaran/sirkuit yang melibatkan serangkaian latihan yang berbeda. Latihan sirkuit dipandang sebagai cara yang efektif dan efisien untuk melatih dalam waktu, jumlah, dan peralatan terbatas (Kumar, Menurut (Suharjana, 2013) bahwa circuit training merupakan suatu metode latihan yang terdiri dari pospos latihan, yaitu antara 8 sampai 16 pos latihan.

Permainan sirkuit terdiri dari beberapa pos kegiatan permainan yang dilakukan secara bertahap dan berkesinambungan. Setiap pos terdapat satu permainan yang menstimulus motorik halus anak. Setiap anak diharuskan menyelesaikan kegiatan yang ada pada setiap pos. Setiap kegiatan atau pos memunculkan kegiatan yang berisi unsur-unsur kegiatan yang disesuaikan dengan tingkat pencapaian perkembangan anak (khususnya motorik halus). Permainan sirkuit akan menjadikan perkembangan motorik anak lebih cepat terstimulus, karena kegiatan pada setiap posnya dirancang untuk demikian. Secara tidak langsung aspek perkembangan yang lainnya pun terstimulus, karena setiap aspek perkembangan saling terkait satu sama lain. Terlebih lagi melalui bentuk sirkuit ini, pola pikir anak akan terstimulus untuk lebih terpola dan terarah. Permainan sirkuit ini lebih baik dilakukan secara outdoor. Melalui permainan sirkuit ini, motorik halus anak dapat distimulasi tanpa membebani anak.

\section{KESIMPULAN}

Permainan sirkuit yang terdiri dari beberapa 4 pos kegiatan pembelajaran. Anak harus menyelesaikan kegiatan yang terdapat pada setiap pos secara urut (mulai dari pos satu ke pos yang lainnya). Adapun pos-pos kegiatan pada permainan sirkuit terdiri dari 4 pos kegiatan, yakni pos 1 adalah menuangkan air kedalam botol, pos 2 adalah mengancingkan benda, pos 3 adalah menjepit gambar dengan jepit jemuran, dan pos 4 adalah menggunting gambar. Hasil analisis data tentang permainan sirkuit dinyatakan efektif dalam meningkatkan motorik halus anak, hal ini dapat dilihat dari hasil hitung J- lebih kecil dari J tabel, maka Ho ditolak. Hal ini membuktikan bahwa terdapat perbedaan yang signifikan antara hasil pretest dan posttest atau adanya perbedaan antara sebelum dan sesudah perlakuan.

\section{DAFTAR PUSTAKA}

Abristiana, P. O., \& Kristanti, A. (2020). Pengenalan Angka Menggunakan Permainan Puzzle Dan Pengaruhnya Terhadap Perkembangan Emosi Dan Kemampuan Motorik Halus Anak Usia Dini Di Play Group Se-Kecamatan Sumbersari Kabupaten Jember. Laplace: Jurnal Pendidikan Matematika, 3(1), 70-86.

Adawiyah Agustina, R., Shofa Ilhami, B., \& Najamuddin. (2015). Pengembangan Model Permainan Tradisional Engklek Edukatif Dalam Mengembangkan Kemampuan Motorik Kasar Dan Kognitif Anak Usia 5-6 Tahun. 5-6.

Agustina, S., Nasirun, M., \& Delrefi, D. (2018). MENINGKATKAN KETERAMPILAN MOTORIK HALUS ANAK MELALUI BERMAIN DENGAN BARANG BEKAS. Jurnal Ilmiah Potensia, 3(1), 24-33.

Britto, P. R., Lye, S. J., Proulx, K., Yousafzai, A. K., Matthews, S. G., Vaivada, T., PerezEscamilla, R., Rao, N., Ip, P., Fernald, L. C. H., Macmillan, H., Hanson, M., Wachs, T. 
D., Yao, H., Yoshikawa, H., Cerezo, A., Leckman, J. F., \& Bhutta, Z. A. (2017). Nurturing Care: Promoting Early Childhood Development. The Lancet, 389(10064), 91-102. Https://Doi.Org/10.1016/S0140-6736(16)31390-3

Chairilsyah, D. (2019). Web-Based Application To Measure Motoric Development Of Early Childhood. JPUD - Jurnal Pendidikan Usia Dini, 13(1), 1-14. Https://Doi.Org/10.21009/10.21009/Jpud.131.01

Effi Kumala Sari. (2014). Peningkatan Perkembangan Motorik Halus Anak Melalui Kegiatan Kolase Dari Bahan Bekas Di Taman Kanak-Kanak Aisyiyah Simpang Iv Agam. Pesona $P A U D, 1(1), 1-11$.

Elfiadi. (2016). Bermain Dan Permainan Bagi Anak Usia Dini. Jurnal Itqan, VII(1), 51-60.

Faris, A., \& Lestari, A. F. (2016). Anak Usia Dini. Teknik Komputer, 2(1), 59-67.

Hasanah, U. (2016). Pengembangan Kemampuan Fisik Motorik Melalui Permainan Tradisional Bagi Anak Usia Dini. Jurnal Pendidikan Anak, 5(1), 717-733. Https://Doi.Org/10.21831/Jpa.V5i1.12368

Khaironi, M. (2018). Perkembangan Anak Usia Dini. Jurnal Golden Age Hamzanwadi University, 3(1), 1-12.

Maghfuroh, L. (2018). Metode Bermain Puzzle Berpengaruh Pada. Endurance, 3(1), 55-60.

Muarifah, A., \& Nurkhasanah, N. (2019). Identifikasi Keterampilan Motorik Halus Anak. Journal Of Early Childhood Care And Education, 2(1), 14. Https://Doi.Org/10.26555/Jecce.V2i1.564

Novitasari, R., Nasirun, M., \& D., D. (2019). Meningkatkan Kemampuan Motorik Kasar Anak Melalui Bermain Dengan Media Hulahoop Pada Anak Kelompok B Paud Al-Syafaqoh Kabupaten Rejang Lebong. Jurnal Ilmiah POTENSIA, 4(1), 6-12. Https://Doi.Org/10.33369/Jip.4.1.6-12

Paramita, M. V. A., \& Sutapa, P. (2019). Pengembangan Model Pembelajaran Berbasis Permainan Sirkuit Untuk Meningkatkan Motorik Halus Anak Usia 4-5 Tahun. Jurnal Golden Age, 3(01), 1-15.

Sofia, A., \& Fatmawati, N. (2019). Bermain Pembangunan Terhadap Keterampilan Motorik Halus Pada Anak Usia Dini. Jurnal Pendidikan Anak, 5(2).

Sugiyono. (2016). Metodologi Penelitian Kuantitatif, Kualitatif, Dan R\&D. In CV Alfabeta. Https://Doi.Org/Https://Doi.Org/10.3929/Ethz-B-000238666

Syahrum, \& Salim. (2012). METODOLOGI PENELITIAN KUANTITATIF.Pdf (P. 184)

Fitriani, R., \& Adawiyah, R. (2018). Perkembangan Fisik Motorik Anak Usia Dini. Jurnal Golden Age, 2(01), 25-34. 
Jurnal Golden Age, Universitas Hamzanwadi

Vol. 04 No. 2, Desember 2020, Hal. 343-350

E-ISSN : 2549-7367

Widyasari, E. H., \& Sutapa, P. (2019). Do Over-Active Kids Have Different Gross Motor Skills? 296(Icsie 2018), 383-386. Https://Doi.Org/10.2991/Icsie-18.2019.70

Yudiwinata, H. P., \& Handoyo, P. (2014). Permainan Tradisional Dalam Budaya Dan Perkembangan Anak. Paradigma, 02, 1-5. 